\title{
不釣合いを利用した制振器の試作*
}

\author{
岩 田 佳 雄*1, 佐 藤 秀 紀*1, 辻村 真 一*2
}

\section{Trial Production of Vibration Controller Using Unbalance}

\author{
Yoshio IWATA, Hidenori SATO and Shinichi TSUJIMURA
}

\begin{abstract}
A vibration controller for rotary machines using an unbalance has been manufactured as a trial. This vibration controller can be easily set on existing rotary machines. The operation for a vibration reduction is similar to the procedure of balancing ; that is, the magnitude and phase of the unbalance of the vibration controller are automatically determined to reduce the vibration of rotary machines. The slider crank mechanism is applied to vary the magnitude of unbalance, and the synchronous control of a rotary machine and the vibration controller enables us to vary the phase of unbalance. A good result for the vibration reduction is shown by the experiment using it for a simple rotary machine.
\end{abstract}

Key Words : Vibration, Vibration Control, Rotary Machine, Balancing, Control of Rotation

\section{1.はじめに}

最近アクティブ振動制御による制振器の開発が盛ん に行われ，回転機械の分野においても多くの例が報告 されている(1). 回転機械の振動はロー夕の不釣合いに よる遠心力が原因となる場合が注とんどであるが、遠 心力は振動を増大するだけでなく，逆にロー夕の遠心 力を打ち消すように作用すれば，振動の抑制も可能で あろうことが考えられる。そこで不釣合いによって遠 心力を発生する装置を試作し，その不釣合いを制御す ることによって回転機械の振動を抑えることを試み た。この制振装置は既存の回転機械に簡単に据え付け て使用することを目的とし，制振対象の回転機械には できるだけ手を加えないように配慮した。

\section{2. 制振器の功作と篗成}

$2 \cdot 1$ 不验合いによるロータの制振 図 1 に示寸 ように $n$ 個の附をもつ回転機械のロータを考える。 それぞれの円板は不釣合い $U_{1}, U_{2}, \cdots, U_{n}$ をもって いる. 各円板の不釣合いと振幅 $A_{1}, \cdots, A_{n}$ の関係は

* 湟稿受付卌成 2 年 6 月22 日。

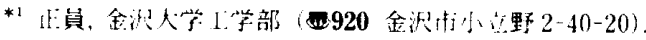

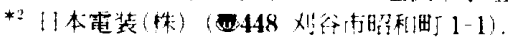

影響係数 $a_{i j}(i, j=1, \cdots, n)$ を使用すると次式のよう に表される(2).

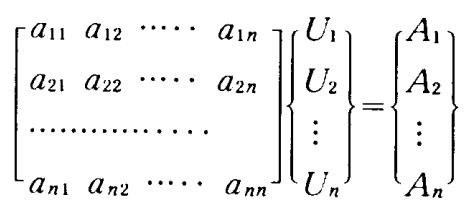

円板 $k$ の振幅 $A_{k}$ は式 (1) から次の上うになる.

$$
A_{k}=\sum_{j=1}^{n} a_{k j} U_{j}
$$

円板 $n$ の不釣合いを調節して円板 $k$ の振幅 $A_{k}$ を零 にするためには，式（2）から円板 $n$ の不釣合いを次の ようにすればよいことがわかる。

$$
U_{n}=-\left(\sum_{j=1}^{n-1} a_{k j} U_{j}\right) / a_{k n}
$$

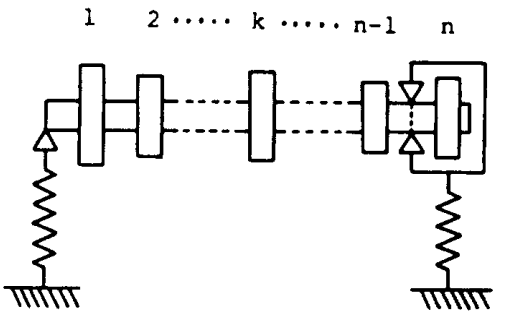

図 1 多円板をもつロータ 
軸受において円板 $n$ の部分をロータから切り離し， ロータと独立して円板が回転するものとする。このと き円板 $n$ がロータと同期回転するならば式 ( 1 )が成 立し, 結果として式(3)のように円板 $n$ の不釣合いに よって円板 $k$ の振幅を零にすることが可能である.す なわち円板 $n$ が制振器の㗢きをし，回転機械の任意の 円板 $k$ の振動を制振する役目を果たしている.この制 振の動作はロータのつりあわせと同じで,つりあわせ を行う要領で制振器の不釣合いを設定すればよい。

$2 \cdot 2$ 制振器の棈造制振器の不釣合いを調節す るためには，不釣合いの大きさと不釣合いの位相を可 変にする必要がある.それを考慮して試作した制振器 の模式図を図 2 に示す. 本試作器の駆動要素として DCモータとステッピングモータが取付けられ，DC モー夕は回転機械と同期して不釣合いを回転させるた め,またステッピングモータは不釣合いの大きさを変 えるために使用されている。

回転している不釣合いの大きさを変える方法とし て, 本試作器ではスライダ・クランク機構を応用した。 DCモータの軸に付けられたスライダとリンクは軸と ともに回転し、リンクの質量が制振器の不釣合いにな る.スライダの軸方向の移動によってリンクと軸との 距離が変化し，不釣合いの大きさが変わる．ステッピ ングモータの回転運動はネジ対偶によって上下運動に 変換され，さらに玉軸受を介してスライダへ伝えられ る.したがってスライダは, 回転しながら DCモー夕 軸の軸方向へ移動することが可能であり，回転する不 釣合いの大きさを調節することができる。

不釣合いの位相についてはDCモータの回転制御に よって行うことにし，回転機械に対して任意の位相を もたせることを可能にした。これについては次章にて 述べる.

試作した制振器の外観を図 3 に示す. 図 2 では DC モータの軸上にスライダ・クランク機構があるが, モ
一夕配置の関係でDC モータとスライダ・クランク機 構の軸を直結することができず，菌付ベルトによって 回転を伝える構造になっている，DCモー夕には回転 数の電圧制御が可能なブラシレスモー夕を使用した。 そのドライバからはモータ 1 回転に対して 12 個のパ ルスが出力され，これをエンコーダとして代用した。

\section{3. 制振器の回転制御}

制振器の DC モータは回転機械と同期して回転する 必要があるとともに，不釣合いの位相をも制御しなけ ればならない。そこで回転数の同期制御と不釣合いの 位相制御を同時に行う制御を試みた。最初, 制振器モ ータおよび回転機械には同じエンコーダが取付けら れ，1回転に出力されるパルス数は等しいものとす る. 制振器モータの始動後から, 制振器モータと回転 機械からのパルス数をカウントするとき，それらのパ ルス数が常に等しいならば両者は同じ回転数で回転し ていることになり，両パルス数に一定の差を持たせれ ば，その差のパルス数に相当する位相差を保って回転 することになる。

回転機械と制振器モータからのパルス数をて秒ご とに測定し，それぞれ $\tau$ 秒前のパルス数との差を $N_{R}$, $N_{i}$ とする. $N_{R}, N_{i}$ は $(i-1) \tau$ 秒から $i \tau$ 秒までの間の パルス数であり， $N_{R}$ は常に一定とする. 回転機械と制 振器モー夕が $n \tau$ 秒後に一定の位相差を保って同期回 転するとき，次式が成立する。

$$
n N_{R}-\sum_{i=1}^{n} N_{i}=\phi
$$

$\phi$ は位相差に相当するパスル数である. 式 (4)を実現 するために $\sum_{i=1}^{n} N_{i}$ をィードバックして制振器モー夕 を制御すればよいが，それだけでは制御系が不安定に なる、そこで両者の回転速度が等しくなる条件,

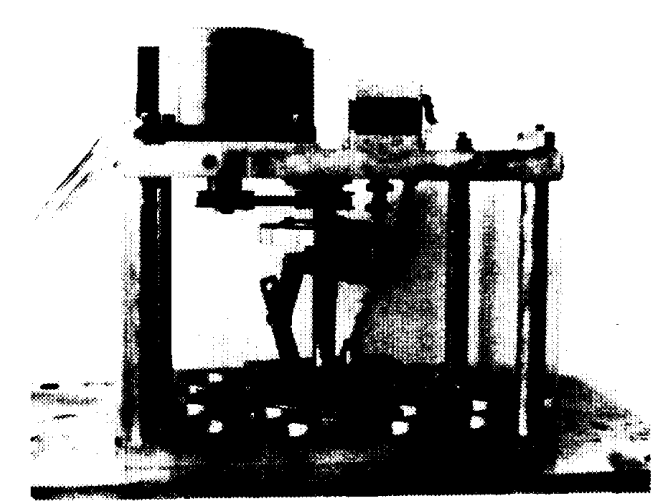

図 3 制振器外覞

図 2 不釣合いの操作機構 
$N_{R}=N_{n}$

も成立するように $N_{n}$ もフィードバックして制御を行 う.フィードバックされた $\sum_{i=1}^{n} N_{i}$ と $N_{n}$ から，次式を使 用して補正電压 $\Delta V_{n}$ を求める。

$$
\Delta V_{n}=k_{1}\left(n N_{R}-\phi-\sum_{i=1}^{n} N_{i}\right)+k_{2}\left(N_{R}-N_{n}\right)
$$

$k_{1}, k_{2}$ はダイン定数である. 制振器モー夕のドライバ へ入力するための $(n+1) \tau$ 秒後の電圧は, $n \tau$ 秒にお ける電圧 $V_{n}$ に式 (6)の補正電圧 $\Delta V_{n}$ を加之,

$$
V_{n+1}=V_{n}+\Delta V_{n}
$$

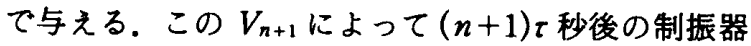
モータの回転速度は次のようになる。

$$
\left(N_{n+1} / \tau\right) / P=A V_{n+1}+B
$$

ここに $A, B$ はモー夕の回転数電圧特性から決まる定 数, $P$ はモータ1回転に対するエンコータのパルス数 である。式(8)から $\sum_{i=1}^{n+1} N_{i}$ と $N_{n+1}$ が求まり，式 (6)の ように $\Delta V_{n+1}$ を計算することができる，以後同様の過 程を綝返して，補正電圧が零，すなかち $V_{n}$ が収束す れば目的の同期制御が達成される。この制御系をブロ ック線図として示すと図4になる。

$V_{n}$ の収束性を $k_{1}, k_{2}$ について調べるために，次の 渐化式を式(6)，(7)，(8)加得る。

$$
V_{n+1}=a V_{n}+b V_{n-1}+c
$$
ただし

$$
\begin{aligned}
& a=2-\tau P A\left(k_{1}+k_{2}\right) \\
& b=-1+\tau P A k_{2} \\
& c=\left(N_{R}-\tau P B\right) k_{1}
\end{aligned}
$$

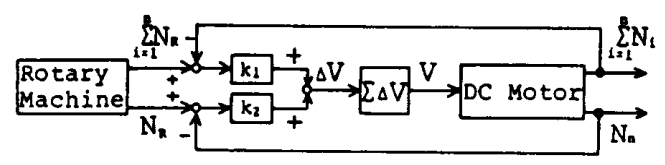

図 4 プロック線図

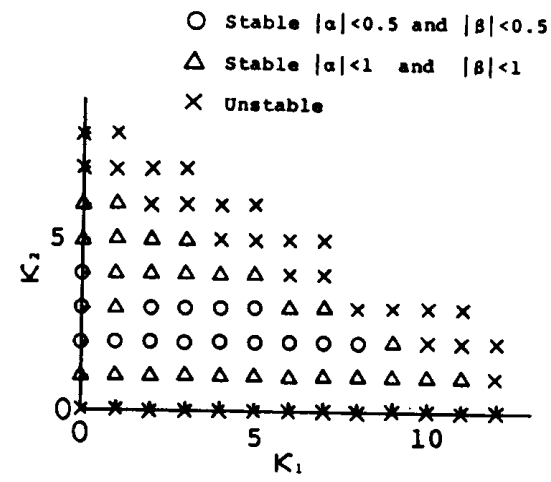

図 5 安定領城 $(\tau=0.5)$
$V_{n}$ が収束するためには, 次の 2 次方程式

$$
x^{2}-a x-b=0
$$

の 2 根 $\alpha, \beta$ の絶対值がともに 1 より小さい必要があ

る. そのときの $V_{n}$ の収束値は次のようになる。

$$
V_{n}=\left\{\left(N_{R} / \tau\right) P-B\right\} / A
$$

これは式 $(8)$ から回転速度 $\left(N_{R} / \tau\right) P$ に対する龟圧に

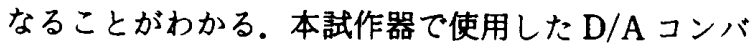
一夕の分解能によって, $k_{1}$ と $k_{2}$ は $1 / 204.8[\mathrm{Volt} /$ パル ス数] 単位で設定できる。したがって,

$$
k_{1}=k_{1} / 204.8, \quad k_{2}=k_{2} / 204.8
$$

と置いて，整数 $k_{1}$ と $k_{2}$ に対して $V_{n}$ の収束判定を行 い，制御系の安定性を調べた、DCモー夕の特性から $A=10.5[\mathrm{rps} /$ Volt], $B=11.7[\mathrm{rps}], P=12$ [パルス]に なる。 $\tau$ を 0.5 秒としたときの安定性を図 5 に示す。 を大きくした場合, 安定領域は原点方向に向かって小 さくなる.この結果から $k_{1}=1, k_{2}=2$ に決定した。

制御器モータと回転機械には同じエンコーダを取付 けるとしてきたが，回転機械にはできるだけ手を加え ないようにするため，回転機械の軸に反射テープを貼 るたけけにして，回転機械からは 1 回転に1パルスだけ を検出することにした．回転機械の l回転ごとに制振 器モータのパルス数をカウントし，回転機械からのパ ルス数を $l \times P$ とすれば前述の制御法を適用すること ができる．ただしては一定でなく，回転数によって変 動することに注意を要する。本試作器においては 1800 $\mathrm{rpm}$ 付近における運転を目的とし，約 0.5 秒ごとにパ ルス測定を行うようにするために 15 回転ごとにパル スをカウントすることにした。

\section{4. 制振器不钓合いの段定}

制振対象の回転機械に振幅測定用のピックアップを ただ 1 個取付け，測定部の振幅が小さくなるように制 振器不釣合いの大きさと位相を決める。ここでは值接 探索法により，不釣合いの位相，大きさの順で試行錯 䛊的に制振器不釣合いを決定する，以下にこの手順を

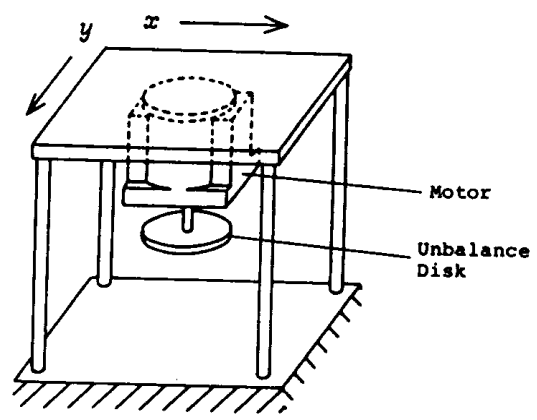

図 6 简単な回転機械モデル 


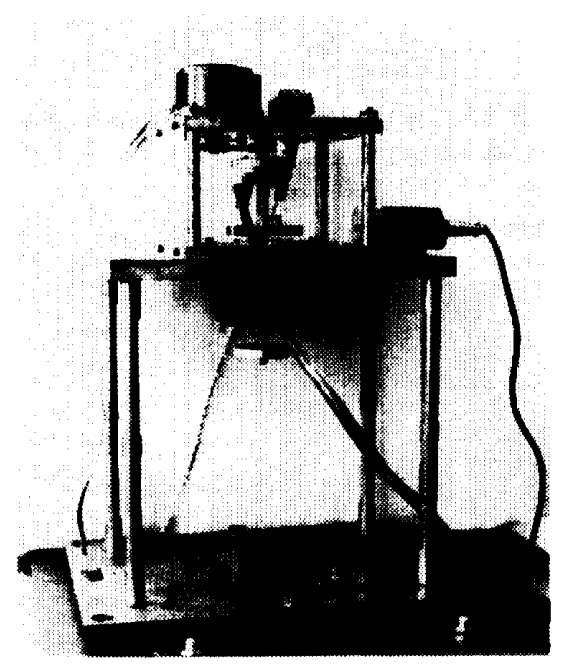

図 7 制振実験外覞

示す.

（1）不釣合いの位相について

位相設定の分解能，この場合には 12 パルス/回転な ので, 30 度単位で位相を変え, 振幅が最も小さくなる 位相を探索する。

（2）不釣合いの大きさについて

位相決定後, 不釣合いの大きさたけを変える．最初 適当なステップで大きさを変え，振幅が最も小さくな る不釣合いの大きさを探索する，次にステップ幅を前 回の半分以下にして探索する，振幅値が許容值内にな るまでこれを綝返す。

\section{5. 制 振 实 跙}

简単な回転機械に対して試作した制振器を設置し， 前章の不釣合い設定法を用いて制振実験を行った。回 転機械は 4 本の支柱から成るたて形構造物に不釣合い 円板をもつモー夕を取付けたもので，その概略を図 6 に示す. 不釣合いモー夕の励振により， $x$ 方向と $y$ 方 向に振動が発生する。支柱の断面は偏平になっている ので, $x$ 方向と $y$ 方向の固有振動数は異なる。この檋 造物の上に制振器を固定し，さらに振動検出用の動電 形ピックアップを $x$ 方向のみに設置した。その外観を 図 7 に示す. $x$ 方向, $y$ 方向の固有振動数はそれぞれ $1845 \mathrm{rpm}, 2070 \mathrm{rpm}$ になった。なお，不釣合い円板 に反射テープを貼り，モータの回転を検出した。

制振器モータを回転せずに，不釣合いモータだけを 回転して振幅応答を測定した結果を図 8 に示す。これ は $x$ 方向, $y$ 方向の振動を非接触変位計にて測定した もので, 不釣合いモータの不釣合いは $87.3 \mathrm{gmm} の と$ きである. 各方向の固有振勳数付近にてピークが生じ ている，図 9 は不釣合いモータの始動時から制振器モ

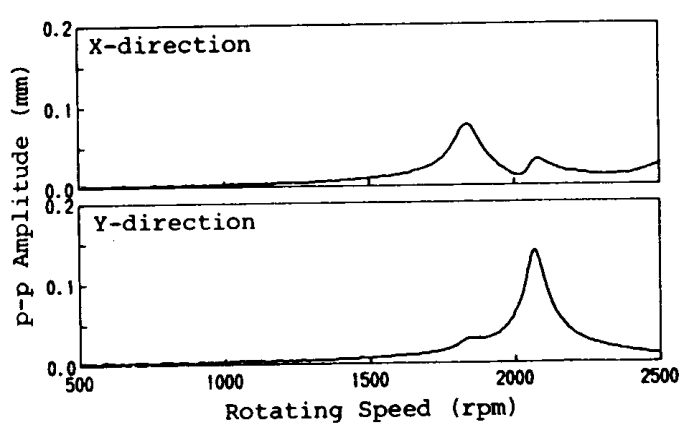

図 8 制振前の応答曲線

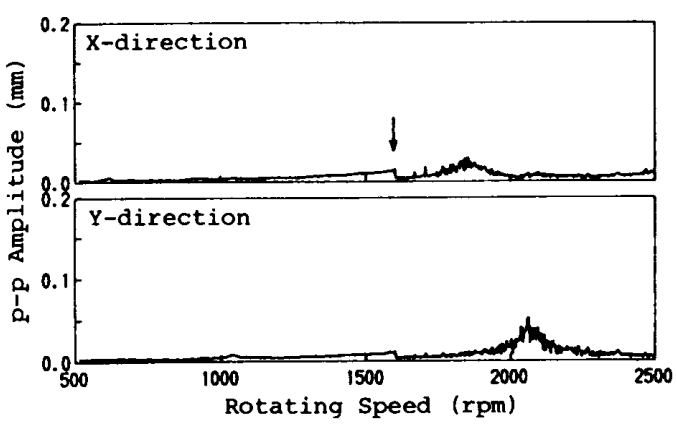

図 9 制振功作中の応答曲線

一夕を同期運転させ, $1580 \mathrm{rpm}$ (図中の矢印)にて制 振操作を行い, その後同期運転しながら不釣合いモー 夕の回転数をゆっくりと上昇させた結果である.危険 速度におけるピークが著しく小さくなっていることか

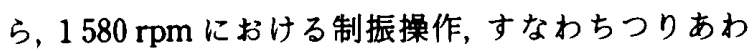
せ動作が良好になされたことがわかる。この動作には 約 80 秒要した。危険速度付近で応答曲線がジグザグに なっているのは, 同期制御によって制振器モータの回 転速度に微小な強制的変動が生じ，そのために発生す る過渡振動が原因になっている。1580 rpmにおいて は $x$ 方向の振動のみを検出して制振操作を行ったが, つりあわせを原理にした制振なので，y方向の振動も 抑制される結果になった。

\section{6. 結}

回転機械に対する制振装置として不釣合いを利用し た制振器を試作した。制振操作はつりあわせの原理と 同じであり，回転機械の振動を小さくするように制振 器不釣合いの大きさと位相を設定する。この制振器は 既存の回転機械に設置して使用することを目的とし， 振動検出器を取付けること,および回轱検出のための 反射テープを軸に貼る程度の変更を回転機械に対して 加えるだけでよい．简単な回転機械に試作した制振器 を設置して実験を行ったところ，良好な制振効果が確 認された。 
最後に本実験装置の製作に協力をいただいた金沢大

学工学部・小川孝吉技官に感謝の意を表する.
文献

（1）野波・ほか 1 名、機論，55-517，C(1989)，2336など

（2）輪・ほか1名，回転機械のつりあわせ，(1979）,217。 